\title{
Radiological irregular opacities and coalwork exposure: a case-referent study
}

\author{
A COCKCROFT,* N ANDERSSON
}

From the MRC Pneumoconiosis Unit, Llandough Hospital, Penarth, S Glamorgan, and TUC Centenary Institute of Occupational Health, London School of Hygiene and Tropical Medicine, London WC1E $3 H T, U K$

ABSTRACT Five hundred and fifteen men newly attending chest clinics in coalmining areas of England and Wales were entered into a study of the risk of irregular opacities on the chest radio graph in relation to occupation; readable radiographs were received for 489 . The men completed questionnaires on occupational and smoking history and the radiographs were read for irregularts opacities by the collaborating chest physicians and by a panel of three readers using the ILO $1980^{\circ}$ classification. Older men had more irregular opacities than younger men, but coalworkers had as significant excess risk of nearly three times of having irregular opacities, which remained afterstratifying for smoking and age. Lung cancer was evident on $14 \%$ of the radiographs and was significantly less common in coalworkers than non-coalworkers. The findings are consistent with a causal association between coalwork exposure and irregular opacities. Other evidence suggests tha these opacities are associated with emphysema in coalworkers.

The textbook description of the radiological appearances in simple coalworkers' pneumoconiosis is of small rounded opacities scattered through the lungs. ${ }^{1}$ Their profusion has not, in general, been found to be related to reductions in lung function. ${ }^{2}$ Recently, it has been reported that irregular opacities on the chest radiograph of coalworkers are associated with emphysema ${ }^{3-6}$ and with reductions in lung function. ${ }^{357}$ It could be argued, however, that these opacities have nothing to do with coalwork and represent some non-occupational process superimposed on coalworkers' pneumoconiosis. There is evidence that irregular opacities are related to coalwork exposure, both in terms of years of underground work ${ }^{8}$ and, more directly, as total lifetime coaldust exposure. ${ }^{9} \mathrm{On}$ the other hand, it has been suggested that, even among coalworkers, the irregular opacities are mainly associated with smoking ${ }^{10}$ and they have been described in smokers with no known occupational exposure to dust. ${ }^{11}$ The profusion of opacities in the latter study ${ }^{11}$ seems to have been low (probably category 1 or less) but the radiographs were not read using an ILO classification. ${ }^{12}$ *Present address: Occupational Health Unit, Royal Free Hospital,
Pond Street, London NW3 2QG.

Accepted 29 September 1986
The aim of the present study was to establish whether coalworkers have an increased risk of radiological irregular opacities. Cases and referents were@ men attending chest clinics in coalmining areas of England and Wales. The study also allowed for an estimate of the background frequency of irregular opacities among non-coalworkers attending chesto clinics.

\section{Subjects and methods}

A multicentre study was undertaken in collaboration with chest physicians in several centres in coalmining areas of England and Wales. Men were enrolled fromo Newcastle (two centres), Merthyr Tydfil, Rotherham, Wakefield, Bridgend, Durham, Darlington, Newport, Nottingham, Ashington, Chesterfield, and Cardiff. The men entered in the study were all those agedor between 40 and 80 who were attending the chest clinic N for the first time. The physician completed a patient N entry form (PEF) for every man eligible for entry, $\sigma$ giving the patient's age, name, and address, and stating whether or not the man was or had been a? coalworker. In addition to these data, which were obtained on all men in the series, the individual was ${ }_{0}^{+}$ asked to complete a questionnaire about hiso occupational and smoking history for a research study. He either completed the questionnaire in the $\frac{?}{\mathbb{Q}}$ clinic and handed it in or took it home and sent it 
back to the pneumoconiosis unit in a stamped addressed envelope provided.

The physician examined the man's chest radiograph, so far as possible without knowledge of his occupational history, and stated on the PEF his or her opinion of whether irregular opacities were present or not. All the collaborating chest physicians were sent copies of two radiographs at the start of the study: one considered to be "borderline" for the presence of irregular opacities and the other a good example of heavy profusion of irregular opacities (more than category 2 on the ILO classification). They were asked to use these films for comparison when reading the study radiographs. The PEF and a copy or duplicate chest radiograph were sent to the pneumoconiosis unit.

Completed PEFs and questionnaires were collated as they were received in the pneumoconiosis unit. A reminder letter and questionnaire were sent to men for whom no completed questionnaire was received within two months of receiving their PEF and a second reminder and questionnaire was sent if the questionnaire had still not been received after a further month. No further follow up was attempted if there was no reply to the second reminder. Entry was stopped when a total of 515 men had been entered.

After entry had been completed, all the duplicate radiographs were collected and read as a single series in random order, with identifying marks obscured, by three experienced readers using the 1980 ILO Classification of Radiographs. ${ }^{13}$ When recording the comment "other disease" in regard to a film, the readers were asked to elaborate further, if possible. The readings of the three readers for shape of small opacities were combined to produce an irregularity score (range 0-9) indicating increasing degree of irregularity of the opacities. The method of obtaining the irregularity score has been described in detail. ${ }^{7}$ Overall profusion of small opacities was taken as the median of the profusions recorded by the three readers.

Cases were those men "with irregular opacities" on the chest radiograph. For the purposes of this study with irregular opacities was taken as being equivalent to category 2 or more profusion of small opacities, with an irregularity score of 6 or more-that is, mainly irregular opacities. Case-referent analysis was performed to determine whether there was an excess of men with a history of coalwork exposure among the cases compared with the referents (all men without irregular opacities as defined above). Age and smoking habits were taken into account by stratification. Relative risk was estimated, and the significance of associations was tested, using the Mantel-Haenszel procedure ${ }^{14}$ and the Mantel extension of this procedure. ${ }^{15}$

\section{Results}

Of the 515 men entered into the study, radiographs were received for 491 and these formed the study group. A total of 189 of the men were, or had been, coalworkers. The proportion of coalworkers varied considerably between centres. Two of the radiographs were considered "unreadable" by all three readers because of poor film quality and therefore only 489 radiographs were included for further analysis.

The panel of three readers identified a total of 19 "cases" of irregular opacities. Coalworkers were significantly more likely than non-coalworkers to be cases of irregular opacities (relative risk $2 \cdot 72,95 \%$ confidence intervals 1.13-6.55) (table 1). A slightly higher proportion of coalworkers than noncoalworkers were current smokers (RR $1 \cdot 06,90 \%$ CI 1.002-1.12) (table 2), but among smokers the coalworkers smoked significantly less than the noncoalworkers $\left(\chi^{2}=4.67, p<0.05\right.$, table 2$)$. The tendency for an increased relative risk of irregular opacities in coalworkers was found in all smoking categories (combined $\chi^{2} 3 \cdot 3$, RR $2 \cdot 4,90 \%$ CI 1.09-5.29) (table 2).

When the data were stratified by age, the same tendency for increased relative risk of irregular opacities in coalworkers was present in all age decades (combined $\chi^{2} 4 \cdot 7$, RR 2.64, 95\% CI 1·1-6.3) (table 3). Men over 60 were more likely than younger men to have irregular opacities. This was true overall $\left(\chi^{2} 5 \cdot 27\right)$ and taking coalworkers $\left(\chi^{2} 4 \cdot 16\right)$ and, to a lesser extent, non-coalworkers $\left(\chi^{2} 1 \cdot 28\right)$ separately (table 3$)$. Superimposed on this effect of age was that of occupation;

Table 1 Case-referent analysis of radiological irregular opacities in coalworkers and non-coalworkers

\begin{tabular}{lcc}
\hline & Coalworkers & Non-coalworkers \\
\hline Cases & 12 & 7 \\
Referents & 177 & 293 \\
\hline
\end{tabular}

Cases and referents as defined in the text.

Table 2 Case-referent analysis of radiological irregular opacities in coalworkers and non-coalworkers, stratifying by smoking history

\begin{tabular}{llcc}
\hline Smoking history & & Coalworkers & Non-coalworkers \\
\hline Non-smokers & Cases & 1 & 0 \\
& Referents & 12 & 37 \\
Ex-smokers & Cases & 2 & 2 \\
Light smokers & Referents & 38 & 70 \\
& Cases & 5 & 1 \\
Heavy smokers & Referents & 43 & 50 \\
& Cases & 3 & 4 \\
& Referents & 62 & 119 \\
\hline
\end{tabular}

Smoking history was unknown, or incomplete, in $\mathbf{4 0}$ men. Light smokers $=<15$ cigarettes a day, heavy smokers $=\geq 15$ cigarettes a day. 
the oldest decade showed the strongest association between coalwork and irregular opacities (RR 4.0, 95\% CI 3.9-4.1) (table 3). Analysis after stratification by centre was not possible because of the few cases at many of the centres.

The radiographs considered by the collaborating chest physicians to show irregular opacities were not all of, or only, those read as cases by the panel of three readers. Table 4 (a) shows the comparison between cases from the panel readings and the chest physicians' readings. Taking the panel readings as the standard, the chest physicians' readings have a repeatability of $82 \%$, a sensitivity of $42 \%$, and a specificity of $20 \%$. The equivalent figures considering only radiographs of coalworkers are $80 \%, 33 \%$, and $29 \%$ (table 4(b)); and considering only radiographs of non-coalworkers $77 \%, 57 \%$, and $15 \%$ (table 4(c)). In other words, the chest physicians "missed" fewer irregular opacities in non-coalworkers, but they also "overread" more irregular opacities in noncoalworkers. Case-referent analysis using the chest physicians' readings of irregular opacities showed a significantly increased relative risk of irregular opacities in coalworkers (RR 2.45, 95\% CI 1.58-3.79) (table 5). The total number of cases of irregular opacities read by the chest physicians was much greater than that read by the panel of three readers (103 v19, see table 4).

Of the 214 radiographs with other disease recorded by the panel of readers, 32 were recorded as showing vascular or cardiac lesions, 31 evidence of tuberculosis, 26 features of emphysema, 20 pleural lesions (thickening, calcification, or effusion), 16 enlargement of the hila or hilar nodes, 15 areas of collapse or consolidation, four evidence of bronchiectasis, and two pronounced distortion of the chest. The most common other disease noted on the chest radiographs was lung cancer, recorded in 68 cases. Coalworkers were at significantly reduced risk of showing an obvious carcinoma on the radiograph (RR $0.53,95 \%$ CI $0 \cdot 32-0 \cdot 87$ ) (table 6).

\section{Discussion}

The frequency of chest radiograph abnormalities in men attending chest clinics would be expected to be high. Nevertheless, the background frequency of irregular opacities (category $2 / 0$ or above profusion, irregularity score 6 or above) among non-coalworkers in this study was only $2 \cdot 3 \%$. A recent study of a working population not exposed to dusts also found a low prevalence of small opacities, both rounded and irregular, of profusion greater than category $1 / 0 .{ }^{16}$ Superimposed on this background frequency among non-coalworkers, the present study shows an excess relative risk of nearly three times of irregular opacities
Table 3 Case-referent analysis of radiological irregular opacities in coalworkers and non-coalworkers, stratifying by age groups

\begin{tabular}{|c|c|c|c|}
\hline $\begin{array}{l}\text { Age group } \\
\text { (years) }\end{array}$ & & Coalworkers & Non-coalworkers \\
\hline \multirow[t]{2}{*}{$40-9$} & Cases & 0 & 1 \\
\hline & Referents & 25 & 56 \\
\hline \multirow[t]{2}{*}{$50-9$} & Cases & 2 & 0 \\
\hline & Referents & 52 & 80 \\
\hline \multirow[t]{2}{*}{$60-9$} & Cases & 6 & 4 \\
\hline & Referents & 69 & 95 \\
\hline \multirow[t]{2}{*}{$70-9$} & Cases & 4 & 2 \\
\hline & Referents & 31 & 62 \\
\hline
\end{tabular}

Table 4 Comparison between readings by the panel of three readers and readings by the chest physicians

\begin{tabular}{|c|c|c|}
\hline \multirow[b]{2}{*}{ Chest physicians' readings } & \multicolumn{2}{|c|}{$\begin{array}{l}\text { Readings by panel of three } \\
\text { readers }\end{array}$} \\
\hline & Cases & Referent \\
\hline \multicolumn{3}{|l|}{ (a) Including all the radiographs } \\
\hline Irregular opacities present & 11 & 92 \\
\hline \multicolumn{3}{|l|}{ (b) Including only coalworkers } \\
\hline Irregular opacities present & 8 & 50 \\
\hline \multicolumn{2}{|l|}{ (c) Including only non-coalworkers } & 124 \\
\hline Irregular opacities present & 3 & 42 \\
\hline Irregular opacities absent & 4 & 239 \\
\hline \multicolumn{3}{|c|}{$\begin{array}{l}\text { For readings by panel of three readers, cases and referents are as } \\
\text { defined in text. }\end{array}$} \\
\hline \multicolumn{3}{|c|}{$\begin{array}{l}\text { Table } 5 \text { Case-referent analysis of radiological irregular } \\
\text { opacities in coalworkers and non-coalworkers, using chest } \\
\text { physicians' readings of the radiographs }\end{array}$} \\
\hline
\end{tabular}

\begin{tabular}{lccc}
\hline Chest physicians' readings & Coalworkers & Non-coalworkers \\
\hline Irregular opacities present & 58 & 45 & 243 \\
Irregular opacities absent & 128 & & \\
\hline
\end{tabular}

Table 6 Radiological evidence of lung cancer in coalworkers. and non-coalworkers

\begin{tabular}{|c|c|c|}
\hline $\begin{array}{l}\text { Lung cancer recorded on } \\
\text { radiograph }\end{array}$ & Coalworkers & Non-coalworkers \\
\hline $\begin{array}{l}\text { Yes } \\
\text { No }\end{array}$ & $\begin{array}{r}17 \\
172\end{array}$ & $\begin{array}{r}51 \\
249\end{array}$ \\
\hline
\end{tabular}

among coalworkers compared with other men attend ing chest clinics for the first time. This is consistent with the suggestion that they are related to coalwork exposure. $^{89}$

Previous studies have reported that irregular opace ities in coalworkers are more common in smokers and older men. ${ }^{78}$ In the present study we are unable to show an association between smoking and irregular. opacities (table 2) either overall or in coalworkers of non-coalworkers separately, possibly due to the smal? 
numbers of cases and of non-smokers. The effect of age was confirmed but, in addition, the oldest decade showed the strongest association between coalwork and irregular opacities. This is consistent with the hypothesis that coalwork exposure, the duration of which is strongly linked to age, is a factor in producing irregular opacities in coalworkers in addition to a general age effect, which is also present in noncoalworkers. The pattern of smoking habits in coalworkers and non-coalworkers found (more smokers but less heavy smokers among coalworkers) agrees with the findings of previous studies. ${ }^{17-19}$

It is perhaps not surprising that the readings of the chest physicians of irregular opacities on the radiographs did not correspond well with the cases of irregular opacities identified from the readings of the panel of three. The chest physicians were asked to state simply whether irregular opacities were present or not, without using any particular scheme of classification. They identified more radiographs as having irregular opacities than were identified as cases from the panel readings. This effect was similar in the noncoalworkers (45 v 7) and the coalworkers (58 v 12). Despite these differences, when the chest physicians' readings for irregular opacities were used there was a significant excess relative risk in coalworkers. The physicians may not have been able to read the radiograph without knowledge of the man's occupation in every case but they would probably have expected rounded rather than irregular opacities on a radiograph known to be that of a coalworker.

In some instances the readers noted that it was difficult to read for parenchymal shadows when severe abnormalities were present-for example, obscuring one lung. There was nothing to suggest that these difficult radiographs were spread unevenly between coalworkers and non-coalworkers (in $61 \%$ of coalworkers and $53 \%$ of non-coalworkers no other disease was noted) so that they should not have biased the results. The many radiographs in this series showing other diseases probably reflects the fact that all the men were attending chest clinics. Obvious evidence of lung cancer was recorded in $14 \%$ of the men (table 6) and, in addition, those recorded as showing lobar collapse or pleural effusion may also have had primary bronchial carcinomas. The finding of less lung cancer among coalworkers is in line with published statistics. ${ }^{20}$

The results of this study are consistent with the hypothesis that irregular opacities in coalworkers are caused by coalwork exposure, since the excess relative risk cannot be explained by smoking or age. This finding is important because of the evidence of association between irregular opacities and emphysema ${ }^{3-6}$ and lung functional impairment ${ }^{357}$ in coalworkers. Thus this study provides further indirect evidence of an occupational basis for emphysema in coalworkers. We are indebted to all the chest physicians who took part in this study: Drs G Anderson, A A Brace, D Bowen, I Campbell, G Chappell, C K Connolly, D Davies, L Erin, J Gibson, J R Lauckner, P O Leggat, D R Lewis, S Nariman, S Pearce, J Scott, E A Spriggs, and J D Stevens. We thank Mrs J Harding for administrative help and $\operatorname{Dr} \mathbf{J} \mathbf{P}$ Lyons and Professor P C Elmes for reading the radiographs.

\section{References}

I Parkes WR. Occupational lung disorders. 2nd ed. London: Butterworths, 1982.

2 Cochrane AL, Higgins ITT. Pulmonary ventilatory function in coal miners in various areas in relation to $x$-ray category of pneumoconiosis. Br J Prev Soc Med 1961;15:1-11.

3 Lyons JP, Ryder RC, Campbell H, Clarke WG, Gough J. Significance of irregular opacities in the radiology of coalworkers' pneumoconiosis. Br J Ind Med 1974;31:36-44.

4 Cockcroft A, Wagner JC, Seal RME, Lyons JP, Campbell MJ. Irregular opacities in coalworkers' pneumoconiosiscorrelation with pulmonary function and pathology. Inhaled particles V. Ann Occup Hyg 1982;26:767-87.

5 Cockcroft A. The importance of irregular opacities on the chest radiograph of coalworkers. London: London University, 1985. (MD thesis.)

6 Davis JMG, Chapman J, Collings P, et al. Autopsy studies of coalminers' lungs. Edinburgh: Institute of Occupational Medicine, 1979. (IOM report TM/79/9.)

7 Cockcroft A, Berry G, Cotes JE, Lyons JP. Shape of small opacities and lung function in coalworkers. Thorax 1982;37:765-9.

8 Cockcroft A, Lyons JP, Andersson N, Saunders MJ. Prevalence and relation to underground exposure of radiological irregular opacities in south Wales coalworkers with pneumoconiosis. Br J Ind Med 1983;40:169-72.

9 Dick JA, Jacobsen M, Gauld S, Pern PO. The significance of irregular opacities in the chest radiographs of British coalminers. In: Bergau-Berufsgenossenschaft. 6th international pneumoconiosis conference, Bochum, 1983. Geneva: International Labour Office, 1984:283.

10 Amandus HE, Lapp NL, Jacobsen G, Reger RB. Significance of irregular small opacities in radiographs of coal miners in the USA. Br J Ind Med 1976;33:13-7.

11 Carilli AD, Kotzen LM, Fischer ML. The chest roentgenogram in smoking females. Am Rev Respir Dis 1973;107:133-6.

12 International Labour Office. ILO-UICC/Cincinnati international classification of radiographs of the pneumoconioses, 1971. Geneva: ILO, 1972. (Occupational safety and health series No 22.)

13 International Labour Office. Classification of radiographs of the pneumoconioses. Geneva: ILO, 1980.

14 Mantel N, Haenszel W. Statistical aspects of the analysis of data from retrospective studies of disease. J Natl Cancer Inst 1959:22:719-48.

15 Mantel N. Chi-square tests with one degree of freedom: extensions of the Mantel-Haenszel procedure. Journal of the American Statistical Association 1963;58: 690-700.

16 Castellan RM, Sanderson WT, Peterson MR. Prevalence of radiographic appearance of pneumoconiosis in an unexposed blue collar population. Am Rev Respir Dis 1985;131:684-6.

17 Cockcroft A, Seal RME, Wagner JC, Lyons JP, Ryder R, Andersson N. Post-mortem study of emphysema in coalworkers and non-coalworkers. Lancet 1982;ii: 600-3.

18 Higgins ITT, Cochrane AL. Chronic respiratory disease in a random sample of males and females in the Rhondda Fach in 1958. Br J Ind Med 1961:18:93-102.

19 Cross KW, McDowell LA. Posner E. Current smoking habits in 1957. Br Med J 1958;ii:862-5.

20 Office of Population Censuses and Surveys. Occupational mortality. The Registrar General's decennial supplement for England and Wales 1970-72. London: HMSO, 1978. (Series DS No 1.) 